\title{
The Effect of Flipped Classroom on Iranian EFL Learners' Speech Act Production: Does Flip Type Make a Difference?
}

\author{
Hasan Alibeigloo ${ }^{1}$, Hossein Ahmadi²* Faramarz AzizMalayeri ${ }^{3}$ \\ 1. Department of English Language, Malayer Branch, Islamic Azad University, Malayer, Iran \\ 2. Assistant professor, Department of English Language, Malayer Branch, Islamic Azad University, Malayer, Iran \\ 3. Department of English Language, Malayer Branch, Islamic Azad University, Malayer, Iran \\ * Corresponding author's Email: ahmadikhm@gmail.com
}

\begin{abstract}
This study investigated the effect of two types of flipped classroom on the Iranian upperintermediate EFL learners' appropriate use of refusals, apologies and requests. The participants of the study included 60 upper-intermediate EFL learners from a language institute in Tehran, Iran. The participants were selected based on convenience sampling in the form of three intact classes. Then, the three classes were randomly assigned to three groups namely, traditional flipping group, debate-oriented flipping group and non-flipping group. The three groups were exposed to 14 treatment sessions. Speech act instruction was offered to the flipping groups through explicit flipped instruction and to the non-flipping group through explicit non-flipped instruction. Moreover, a Multiple Choice Discourse Completion Test (WDCT) was administered to the participants to measure their speech act production ability at the pre-treatment and posttreatment, phases of the study. The results revealed that both types of flipped instruction had a significantly positive effect on the EFL learners' use of the speech acts $(F=10.622, p<.0 .05 ; F=19.358, p<.0 .05 ; F=18.785$, $\mathrm{p}<.0 .05)$. Accordingly, EFL teachers are recommended to use flipping methods in an attempt to enhance EFL learners' appropriate use of speech acts.
\end{abstract}

Keywords: Flipped instruction; Pragmatics; Speech acts

\section{Introduction}

The use of technology in language learning and teaching began in early 1970s and since then, it has found its way into the field rapidly (Karakash\&Ersoy, as cited in Elyasi\&Pourkalhor, 2014). Some scholars (e.g., Agca\&Özdemir, 2012) believe that technology makes foreign language materials easy to access and use, and makes language learning more meaningful through personal engagement. "Technological developments in ubiquitous computing and wireless communication together with the adoption of mobile multimedia devices and applications have been converted into huge opportunities for English as a foreign language" (Rodríguez-Arancón, Arús\&Calle, 2013, p. 1189).Technology can be used in different forms in different fields. As in other fields, the use of technology has become increasingly widespread in education but selecting the most proper technology tools is controversial because of such a variety of hardware and applications. An important issue in selecting technology tools is that the task of acquiring a second language should not be made more difficult by using unnecessary and complicated tools. Many research studies have been conducted on the use of technology in the instruction of English language learners (E.G., Dooley, 2009; Narciss\&Koerndle, 2008; Sahin, 2009). Technology skills are identified as critical for professional success in the 21 st century, and English 
language learners expressed satisfaction about these skills (Ibarz\& Webb, 2007). This may be especially important in the case of English language learners because development of their own technology knowledge may help them provide direction to their future children in an increasingly technological world and help students feel comfortable and less inhibited when speaking aloud in their second language (Gibson, 2008). Simplicity of directed guidelines, active learning opportunities, and joint learning settings may help achieve a balance between English language acquisition and the development of relevant 21 st century skills. In addition, classroom activities that are repetitive and restricted may help the creation of these kinds of learning opportunities, especially in technology skills classes taught in English (Gibson, 2008).

As one of the world's more important educational topics, and as a dominant manifestation of technology use in EFL learning, flipped learning can be mentioned. Flipped learning is "a learning model where students learn the online course materials first, then have their questions answered by the teacher, and participate in the guided discussion and experiments during the classroom hour" (Lin \& Chen, 2016, p. 232). This kind of learning has been formed under the influence of the internet and information technology (Lin \& Chen, 2016). In flipped learning, the traditional role of teachers as being a knowledge provider changes to a facilitator and coordinator of the students' learning process; moreover, the role of students changes from the copying and memorization equals high test scores learning model to that of a self-initiating learner model (Kvashnina\&Martynko, 2013) .

Flipped learning aims at motivating and engaging students "in an interactive way, presenting new information outside of class and focusing on higher level cognitive learning together with the teacher, in class" (Kvashnina\&Martynko, 2013, p.71). It has always been a challenging task for learners to be engaged in learning materials. This is while according to Reeve and Lee (2014), learner engagement predicts course achievement and high-quality classroom engagement contributes the understanding, prediction, and potential facilitation of constructive changes in students' course motivation. According to Tomlinson (2011, as cited in Rahmanpanah\&Mohseni, 2017), understanding engagement in learning context is an important issue for language teachers as they can create positive learning outcomes from the learners.

Clearly, it cannot be denied that with the advances in technology and due to technological innovation, implementation of flipped learning has become easier for educators because they can compile and distribute study materials that are also engaging for learners (Berrett 2012). However, the willingness of students to participate in learning is one of the important elements of successful implementation of flipped learning (Kvashnina\&Martynko, 2013). Accordingly, one of the main challenges teachers face in implementing flipped learning is preparing students. This is while flipped learning is appropriate for students with special needs and learners of different acquisition paces, using various free video creation tools available like Screencastomatic, Camtasia, OfficeMix, Educreations (Moranski\& Kim, 2016) . Furthermore, speech acts, as functional subcomponent of pragmatic competence, are considered as one the important research areas in the field of English Language Teaching (ELT) due to the attention to pragmatic competence as the second facet of language competence (Kasper, 2000). Moreover, they play 
an important role in the appropriate use of language according to context. Speech act knowledge consists of language user's sociocultural knowledge and his/her sociolinguistic knowledge. "Sociocultural knowledge is a kind of competence a speaker needs in order to apply speech act strategies properly. Sociolinguistic knowledge refers to context awareness ability in order to appropriately apply vocabulary, linguistic forms, register and politeness and research done in this area centers on perlocutionary acts" (Sadri Allami, \& Rezai, 2018, p. 21). Moreover, according to Austin (1962), communication is an event and a series of communication acts to bring about some effect on the environment of hearers and speakers. Pragmatic competence is considered as important factors in success of communication (Sadri, Allami, \& Rezai, 2018). Leech (1983) states that the main role of pragmatic competence is "avoiding disruption and maintaining the social equilibrium and friendly relations" (p. 23). In linguistic theory, it is an important issue relevant to relational communication (Sadri, Allami, \& Rezai, 2018).

The fact is that although number of advocates of flipped learning and educators showing interest in the topic is increasing, there is no consensus on the matter that using this technique will result in success; in other words, flipping lessons have led to contradicting results in different fields including science, technology, engineering, math, etc. (Moranski\& Kim, 2016). Moreover, the volume of research on the use of flipped classroom in language lessons is not rich (Kvashnina \& Martynko, 2016) .

The other problems associated with flipped classrooms are that teachers are not sure whether students will actually watch the assigned video at home; teachers find planning and building of videos difficult and time-consuming; implementing flipped learning requires additional skills on the part of teachers, etc. (Davis, 2016). In sum, as put by Goodwin (2013, as cited in Davis, 2016), we have no access to a scientific research base showing how and to what extent flipped classrooms work and become successful. In a similar vein, according to Bell (2015), the flipped classroom cannot be accepted and understood as a valid method of instruction because there has been little research on the effectiveness and efficiency of flipped classrooms in students' learning (Bell, 2015).

The other problem related to flipped learning is that in spite of increasing popularity of this method worldwide, having a glance at Iranian educational system shows that still traditional teaching methods and techniques are prevalent in many educational settings and just recently computer-assisted language learning has come to be applied in some educational environments. Thus, naturally many language teachers and learners are not familiar with the potentials of this technology for language teaching and learning .

Just recently electronic devices and materials have been applied in the Iranian educational system and particularly English language teaching. Thus, inevitably many stakeholders in ELT field, including English language teachers are not familiar with the new positive opportunities and potentials of incorporating flipped learning into English language teaching programs. In other words, despite the evident popularity and potential of technology and its important role in education, many university students and teachers do not make much academic use of technological devices in teaching and learning. This can be attributed to some reasons among which lack of necessary facilities, lack of necessary expertise among teachers and students in applying technology, shortage of time, etc. can be mentioned . 
Furthermore, language classroom is a place wherein various functions of language are used by interlocutors to establish a communication system, and wherein the teacher-student interaction can contribute to students' language development (Consolo, 2006). Accordingly, the importance of pragmatic competence cannot be denied in the context of language classroom and consequently in the quality of interaction which occurs between students and teachers and consequently the quality of learning. However, sometimes, it is seen that teachers complain about inappropriate behaviors of students in their classes; this is while, as noted by some scholars, learning a foreign language requires the knowledge of how to speak and write, and how to behave appropriately (Senowarsito, 2013) .

In addition, because pragmatics as a field is not very old in second/foreign language acquisition (S/FLA), the amount of works done in this regard is not huge, at least in EFL contexts. What worsens the situation is the belief among students that correct use of grammatical rules is more serious and important than appropriate use of language while the important role of pragmatics or appropriate use of language cannot be denied (Lee, 2009) .

However, in spite of the mentioned significance of pragmatic competence in the quality of communication and interaction between students and teachers in language classes, and more importantly, the role of pragmatic competence in the quality and amount of students' learning, to the best knowledge of the researcher, few studies have dealt with pragmatic competence in flipped classrooms in the Iranian context. As an attempt to fill this gap, this study was conducted.

To fulfill the purpose of the present study, the following research questions were addressed:

1. Do different types of flipped classroom significantly impact the Iranian upper-intermediate EFL learners' appropriate use of refusal?

2. Do different types of flipped classroom significantly impact the Iranian upper-intermediate EFL learners' appropriate use of apology?

3. Do different types of flipped classroom significantly impact the Iranian upper-intermediate EFL learners' appropriate use of request?

\section{Literature Review}

The flipped classroom is considered a recent idea in the education field. The most commonly cited creators of the flipped model are Bergmann and Sams when they flipped their high school chemistry classes in 2007 (Brame, 2013). However, some of the basic concepts of the flipped classroom have been there since the 1990's (Brame, 2013). When Bergmann and Sams flipped their classes and found that their students' test scores improved, they began to publish their findings and established a non-profit organization to assist other teachers in the process of flipping their classrooms (Brame, 2013).

Brame (2013) defined flipping the classroom as exposing students to new material outside of class through reading or lecture videos, and then using class time to assimilate the knowledge obtained from new material through problem-solving, discussion, or debates. The flipped learning is concerned with the idea that students should come to class more prepared than before (Hung, 2015) . 
The flipped classroom technique is aimed at motivating students and engaging them interactively, through presenting new information outside of class and assigning class time to higher level cognitive learning (Kvashnina\&Martynko, 2013) .

As an example of a flipped classroom, teacher can provide students with a grammar topic in video as homework so that students become ready to do tasks in class that might be too difficult to do on their own. Flipping the whole classroom or course might not be beneficial so it is for the teacher to decide on the amount of flipping, making terms like flipped learning or flipped lessons more appropriate at times (Ash, 2012) .

Ash (2012) suggested continue flipping classrooms based on an evaluation report on flipping the classroom, but he believed that the amount of flipping should be determined according to the needs of students. As stated by Sams and Bergmann (2013), videos should be used selectively rather than generally for all situations and all kinds of instruction. As there are students with different learning styles in any class, it is important for the instructor to use various methods and techniques of teaching in order to reach everyone (Sams\& Bergmann, 2013).

" Using flipped learning enables students to communicate more in class and receive immediate feedback from the teacher" (Hung, 2017, p. 182). According to Doman and Webb (2016), the main motive behind flipping the classroom reducing the teacher talking time in the classroom and providing students with opportunities to engage in discussions with peers. In other words, increasing student engagement is considered as the main idea behind flipped classroom model .

Interestingly, Sams and Bergmann (2013) believed that flipped learning is not new because it has been there centuries ago when teachers wanted their students to come to class prepared through reading a text or a part of a text at home. The only difference is that today in flipped classrooms, students become prepared more conveniently thanks to technological advances including audiovisual devices (Berrett, 2012).

Empirically, JoshaghanNezhad and Bagheri (2018) studied the impact of a flipped lesson on academic motivation and student learning in computer course. In the present study, a semi-experimental research project has been used. In the control group, the traditional education method was used and in the experimental group, a flipped class method was used. Harter's classroom affect and motivational questionnaire was used to collect data. Based on the results of the research, the average student's academic motivation in flipped classes was higher than the traditional one, although there was no significant difference between them and only the external motivation component was significant. Also, the mean of students' learning in flipped classes relative to the classroom was increased, although no significant difference was reported and there was a significant difference between the groups in the practical learning subscale .

Kaviani et al. (2017) studied a learning process in the flipped class. The purpose of this study was to investigate the learning process in the flipped class which was carried out systematically based on the qualitative method and the research method of data theory of the foundation. The unit of analysis included 17 undergraduate students in educational science at the academic year 2016-2017 in a 
university classroom that were trained in 12 sessions. The main instrument of the research is a semistructured interview. Findings showed that the main focus of the learning process of students is in the flipped learning of active learning, which is influenced by factors such as causal conditions (external and internal motivation); The strategies of the learning process (collaborative, exploratory, independent and deep); the field (time management, teaching materials and lesson plans), and intervening conditions (individual, educational, organizational and cultural factors), which ultimately lead to improved outcomes (individual and educational) of the students .

Haqqani et al. (2016) examined a flipped class as a method of training in a study. The purpose of this study was to review the concept of flipped class. In this paper, 28 papers, 4 theses and 2 books were used to review the study. First, this educational method was described and then its advantages and limitations were mentioned. The results suggested that flipped class is an educational method that includes two separate direct instructional outside of class and group in-class education .

Lin and Chen (2016) investigated whether flipped classroom impacts the learning effectiveness, taking the mediating role of learning satisfaction into account. As revealed by the findings, as perceived by both the instructors and students of technical and vocational colleges, flipped learning positively influences learning satisfaction. Moreover, it was indicated that the instructors and students perceive that learning effectiveness is positively influenced by flipped learning. As the third finding, learning satisfaction mediates the effect of flipped learning on teaching effectiveness .

MobserMaleki (2015), conducted a research entitled 'Use and Effect of the Flipped Teaching Method', on learning the activities of the 8th grade high school Course Work and Technology Lessons. The research method was quasi-experimental and the statistical population included 8th grade high school students in district 1 of city Baharestan of Tehran province. The research tool was a teacher-made checklist. The results of this research were: 1- The difference in learning averages in students in the control and experimental group is significant. 2. The group that was taught through flipped learning has a better performance than the traditional teaching method. 3. The effect of flipped learning is positive, so flipped education can be said to be a new approach for providing a free, flexible, and distributed learning environment for anyone at any time .

Said Ahmed (2016) aimed at investigating the effect of a flipping classroom on writing skill in English as a foreign language and students' attitude towards flipping. The study sample consisted of 60 students at Qassim University. The instruments of the study were an EFL writing test and a questionnaire to measure students' attitude towards flipping. Results of the study showed that the experimental group outperformed the control group in the post-test of EFL writing. Second, there was statistically significant difference between the mean scores of the pre and post application of the questionnaire of the experimental group in favor of the post application. This difference was attributed to using flipping.

Sung (2015) looked into a flipped English content-based class where 12 participating college students were enrolled and completed all the course requirements in an elective course. Before each class, the students were guided to preview lesson materials such as readings and videos and to engage in diverse online activities on an LMS flat form. Then, they did collaborative class activities such as sharing their 
Thought Papers, discussing the questions on weekly readings developed online, and doing a final project of designing an evaluation plan. The results of the analysis of both informal and formal course evaluations and student work showed that they viewed flipped learning positively despite initial difficulties of adjusting themselves to it. They also viewed that flipped teaching can be a good momentum for change in current English language teaching .

Webb, Doman, and Pusey (2014) conducted an experiment with intermediate level EFL classes at a university in Macau, China. Data from observations and surveys revealed that initially, the flipped model did not match learner expectations of teacher roles in the classroom. However, at the end of the 15 -week course, students in the experimental classes requested additional flipped materials and appeared more comfortable with the model. Additional findings from teaching journals uncovered that three out of the four teachers recommend the flipped approach for promoting creativity and opportunities for higher order learning in the classroom. The journals also indicated some skepticism among teachers in regards to applying the flipped concept to language instruction and struggles with student engagement with the materials .

Mireille (2014) examined the impact of using a flipped classroom instructional method on the writing performance of the twelfth grade Emirati female students and identify female students' perception of the Flipped Instruction in an ESL writing setting. For this purpose, a 15-week teaching program was designed to cover the main IELTS Tasks 1 and 2 writing objectives. The program consisted of instructional videos and differentiated class tasks that were used with only one group of students while the other group studied the teaching material in a similarly learner-centered class. Both groups completed a pretest and post-test to answer the inquiry of the study. Findings revealed statistically significant differences between the mean scores in favor of the students in the experimental group. This improvement in the writing performance was attributed to the Flipped Instruction method of teaching. Students' attitudes towards the Flipped Instruction proved to be equally favorable .

Butt (2014) investigated the flipped classroom in his final-year actuarial course in Australia. By giving a two-part questionnaire to his students, he found that students perceive that they learn the most from performing an activity and that they prefer individual study over lectures, tutorials, and group study. By comparing students' attitudes at the beginning of the semester and then again at the end, Butt found that students who originally viewed the flipped classroom unfavorably at the beginning of the course began to change the opinions about this by the end of the class .

Baranovic (2013) examined the impact of flipping on his first-year composition course at a university in the United States. By creating multimedia lecture videos, he eliminated the need for traditional lectures and replaced these with creative writing-style workshops. To facilitate the workshop, his classroom became a circular, communal space of socially constructed standards, encouraging a collaborative recursive writing process and stimulating creative thinking in his students. Results showed that the course benefitted students of all writing levels, in particular non-native English speakers. Students are invested heavily in the workshop and in each other's writing, and their writing exceeded the standards set by the university. 


\section{Material and Methods}

This study was quasi-experimental, pre-test, posttest, and control group in design. In this type of design, experimental and control groups are used. The experimental group is given the treatment but the control group did not receive it, over a fixed period of time. However, the experimental and control groups undergo exactly the same tests in the form of pre-test and post-test. Statistical analyses are then used to determine if the intervention had a significant effect (Ary, Jacobs, Sorensen Irvine, \& Walker, 2019).

\section{Participants}

Three classes of EFL learners $(n=71)$ from a language institute in Tehran, Iran, sat the Quick Placement Test. Their EFL proficiency was found to be upper-intermediate as determined by QPT at the outset of the study. However, some of the learners $(\mathrm{N}=5)$ were not at the upper intermediate level of EFL proficiency as determined by their QPT and some of the them $(\mathrm{N}=6)$ did not attend the tests and the treatment sessions completely. Therefore, the final statistical analysis was conducted on data obtained from 60 EFL learners. As mentioned in research textbooks (e.g., Ary, Jacobs, Sorensen Irvine, \& Walker, 2019), this sample size is considered acceptable for educational research. The age range of the learners was between 20-26. None of them had the experience of staying in an English-speaking country. The results of a One-way ANOVA conducted on the QPT scores indicated that the three classes were homogeneous in terms of EFL proficiency (in the score range of 40-47). Then, the three classes were assigned to three groups namely, traditional flipping group $(\mathrm{N}=20)$, debate-oriented group $(\mathrm{N}=20)$ and non-flipped group $(\mathrm{N}=20)$. All participants were male, their age range was 20-26 and their language proficiency was upper-intermediate

\section{Instruments}

Two instruments were applied to collect the required data: The Quick Placement Test (QPT), and a Written Discourse Completion Test (WDCT).

QPT: The Quick Placement Test (QPT), developed by Oxford University Press and the Cambridge ESOL Examination Syndicate, was employed to ensure the homogeneity of the participants regarding their language proficiency. This test includes 60 multiple-choice items (20 grammar items, 20 vocabulary items, and 20 cloze test items). This test was utilized to identify the upper-intermediate EFL learners (i.e. those gaining scores between 40 and 47). The complete test took about 30 minutes to complete. Moreover, the reliability index was found to be .79, as indicated by Cronbach's Alpha coefficient. Also, for the purpose of the present study, the test validity was confirmed by expert judgment.

Written Discourse Completion Test (WDCT): A multiple choice Written Discourse Completion Test (WDCT), adapted from Birjandi and Rezaei (2010), was used as pre-test and post-test. It was adapted in the sense that the original test consisted of 20 items (10 items on request and 10 items on apology) and the researchers added 8 items on refusal (taken from Tajeddin \& Bagherkazemi, 2014) to it. Accordingly, this test consisted of 28 multiple choice items. Each item of the test described a situation; there were three responses following each situation; the respondents were asked to read the 
responses to each situation and decide which one is the BEST in each situation. For the purpose of this study, the whole test was validated by a team of three EFL university professors. To be more specific, three EFL university professors were asked to comment on the items so that necessary revisions could be made on them. Moreover, it was found to be of a Cronbach's reliability index of .87 .

\section{Procedure}

To collect the required data, three intact classes were randomly divided into three groups including two flipping groups namely, traditional flipping group (Basaran, 2019) and debate-oriented group (Basaran, 2019), and a non-flipping group.

In the next stage, the WDCT was implemented in the three groups as the pre-test in 40 minutes. Next, the three groups were exposed to 14 sessions of instruction on the appropriate use of refusals, apologies, and requests. Group one received traditional flipped instruction, group two was exposed to debateoriented flipped instruction, and group three received non-flipped instruction on the appropriate use of the speech acts.

In the traditional flipping group, the researcher (as the teacher of the group) recorded video lectures and send them to the participants before each class session. In the recorded videos, some information on the appropriate use of refusal, apology, and request was presented by the teacher using figures (shapes) and real-life examples. Moreover, some examples of the inappropriate use of refusal, apology, and request were presented along with their appropriate equivalents. These examples were taken from the existing sources on the speech acts including textbooks (e.g., Searle, 1969) and articles (e.g., Birjandi \& Rezaei, 2010). Also, some demonstrations were incorporated in the videos. In demonstrations, the learners were taught how to use refusal, apology, and request speech acts in a step-by-step process. As demonstrator showed how, he also told what he was doing. For example, the teacher demonstrated the way a student can apologize his/her for their bad behavior in class by saying "Dear teacher! I would like to apologize for my behavior in art class yesterday afternoon". In addition, some researcher-made PowerPoint files including information on the appropriate use of refusal, apology, and request were sent to the experimental groups before class sessions. The content of the PowerPoint files was based on the relevant resources about the use of speech acts including textbooks and articles (e.g., Searle, 1969). The learners were asked to watch the videos and read the PowerPoint files at home before coming to class.

In the traditional flipping group, in the class sessions, first, the researcher got feedback from the participants on what they watched in the videos and read in the PowerPoint files. In case any misunderstandings or questions existed, the researcher provided the participants with more explanations. In the debate-oriented group, in addition to the procedures mentioned for the traditional flipping group, in each class session, two or three participants were voluntarily or randomly asked to give presentations on what they learned from the videos and the Power Point files. Moreover, in the debate-oriented group, the students debated and exchanged their ideas in the classroom about the videos and the PowerPoint files. 
However, the learners in the non-flipping group were exposed to explicit instruction on the appropriate use of the speech acts. One week after the end of classes, the WDCT was administered to the three groups as the post-test in 40 minutes.

To analyze the data, descriptive and inferential statistics were used using SPSS21 software. Descriptive statistics included mean, standard deviation and standard error of mean. Inferential statistics involved one-way analysis of variance (ANOVA).

\section{Results}

The results of normality test showed that the data was normally distributed at $\% 95$ confidence level. This normal distribution showed that for data analysis and mean comparison, parametric tests could be used.

First, descriptive statistics was calculated to measure the participants' appropriate use of refusals, apologies and requests in the pre-test and post-test, respectively. Table 1 shows the results.

Table 1. Descriptive Statistics

\begin{tabular}{|l|l|l|l|l|}
\hline \multicolumn{2}{|l|}{ Group } & Refusals (pre/post) & $\begin{array}{l}\text { Apologies } \\
\text { (pre/post) }\end{array}$ & $\begin{array}{l}\text { Request } \\
\text { (pre/post) }\end{array}$ \\
\hline \multirow{3}{*}{ Traditional flipping } & $\mathrm{N}$ & $20 / 20$ & $20 / 20$ & $20 / 20$ \\
\cline { 2 - 5 } & Mean & $4.7000 / 6.7500$ & $5.2000 / 7.7000$ & $4.9000 / 6.6000$ \\
\cline { 2 - 5 } & Std. Deviation & $.80131 / .96655$ & $.89443 / 1.21828$ & $.96791 / 1.09545$ \\
\hline \multirow{5}{*}{ Debate-oriented } & $\mathrm{N}$ & $20 / 20$ & $20 / 20$ & $20 / 20$ \\
\cline { 2 - 5 } & Mean & $5.0000 / 7.6500$ & $4.8000 / 7.8500$ & $4.9500 / 7.0000$ \\
\cline { 2 - 5 } & Std. Deviation & $.79472 / 1.18210$ & $.52315 / 1.18210$ & $.94451 / 1.41421$ \\
\hline \multirow{3}{*}{ control } & $\mathrm{N}$ & $20 / 20$ & $20 / 20$ & $20 / 20$ \\
\cline { 2 - 5 } & Mean & $4.8000 / 5.0500$ & $4.1000 / 5.0500$ & $4.3000 / 4.5500$ \\
\cline { 2 - 5 } & Std. Deviation & $.69585 / .82558$ & $.76777 / .82558$ & $1.30182 / .94451$ \\
\hline
\end{tabular}

Table 1 shows that the mean scores obtained for appropriate use of refusals by the traditional flipping, debate-oriented and control groups were 4.70, 5.00, and 4.80, respectively. Moreover, the standard deviation values obtained included $.80, .79$, and .69 .

Furthermore, as shown in Table 1.2, the mean scores of the appropriate use of refusals of the traditional flipping, debate-oriented and control groups were 6.75, 7.65, and 5.05, respectively. Moreover, .96, 1.18 , and .82 were obtained as the standard deviations of the three groups, respectively.

In addition, Table 1 indicates the mean scores of 5.20, 4.80, and 4.10 for the appropriate use of refusal of the traditional flipping, debate-oriented and control groups, respectively. Furthermore, .89, .52, and .76 were obtained as standard deviation values of the three groups respectively.

Regarding the post-test scores, as seen in Table 1, the mean scores of the traditional flipping, debateoriented and control groups' appropriate use of apology in the post-test were 7.70, 7.85 and 5.05, respectively. The standard deviation values for the three groups were 1.21, 1.18, and .82, respectively. The mean and standard deviation of the traditional flipping group's appropriate use of requests in the pre-test were 4.90 and .96 , respectively. The values obtained for the debate-oriented flipping group were 4.95 and .94 , respectively. The values for the control group were 4.30 and 1.30, respectively. 
Moreover, 1.6, 6.60, 7.00, and 4.55 were obtained as the mean scores of the traditional flipping, debateoriented and control groups in the appropriate use of request in the post-test, respectively. Moreover, the values of the standard deviations of the three groups were 1.09, 1.41, and .94, respectively.

Then, at the inferential level, the three groups' mean scores in the pre-test and post-test were compared with each other through running one-way ANOVA. The results of one-way ANOVA for the scores in the pre-test and post-test are shown in Table 2.

Table 2. Results of One-way ANOVA

\begin{tabular}{|c|c|c|}
\hline Variable & F & Sig \\
\hline Refusal - Pre & .383 & .684 \\
\hline Refusal - Post & 10.622 & .000 \\
\hline Apologies- Pre & 2.467 & .94 \\
\hline Apologies - Post & 19.358 & .000 \\
\hline Request-Pre & 2.020 & .142 \\
\hline Request- Post & 18.785 & .000 \\
\hline
\end{tabular}

As shown in Table 2, the observed between-group differences in the refusal, apologies and request posttest are significant $(\mathrm{F}=10.622, \mathrm{p}<.0 .05 ; \mathrm{F}=19.358, \mathrm{p}<.0 .05 ; \mathrm{F}=18.785, \mathrm{p}<.0 .05)$. This means that there is a significant differences among the means of the three groups on the post-test. To locate the significant difference(s), the Tukey post hoc test was used, the results of which are shown in tables 3 to 5 .

Table 3. Results of Tukey Post hoc Test for Refusal Post-test

\begin{tabular}{|c|c|c|c|c|c|}
\hline \multirow{2}{*}{ (I) Group } & \multirow{2}{*}{ (J) Group } & \multirow{2}{*}{ Std. Error } & \multirow{2}{*}{ Sig. } & \multicolumn{2}{|c|}{$95 \%$ Confidence Interval } \\
\cline { 3 - 6 } & & & & Lower Bound & Upper Bound \\
\hline \multirow{2}{*}{ Traditional flipping } & Debate-oriented & 2.37414 & .715 & -4.0178 & 7.9170 \\
\cline { 2 - 6 } & Control & 2.37414 & .000 & 4.3326 & 16.2674 \\
\hline \multirow{2}{*}{ Debate-oriented } & Traditional flipping & 2.37414 & .715 & -7.9170 & 4.0178 \\
\cline { 2 - 6 } & Control & 2.37414 & .004 & 2.3830 & 14.3178 \\
\hline \multirow{2}{*}{ Control } & Traditional flipping & 2.37414 & .000 & -16.2674 & -4.3326 \\
\cline { 2 - 6 } & Debate-oriented & 2.37414 & .004 & -14.3178 & -2.3830 \\
\hline
\end{tabular}

The Tukey test (table 3), indicated that the mean scores of the traditional flipping and debate-oriented groups were significantly higher than that of the control group. This shows that both flipping methods had significant instructional effects on the appropriate use of refusals. However, there is no significant difference between the traditional flipping and debate-oriented flipping in terms of their effectiveness. 
The Effect of Flipped Classroom on Iranian EFL Learners' Speech Act Production...

Table 4. Results of Tukey Post hoc Test for Apology Post-test

\begin{tabular}{|c|c|c|c|c|c|}
\hline \multirow[t]{2}{*}{ (I) Group } & \multirow[t]{2}{*}{ (J) Group } & \multirow[t]{2}{*}{ Std. Error } & \multirow[t]{2}{*}{ Sig. } & \multicolumn{2}{|c|}{$95 \%$ Confidence Interval } \\
\hline & & & & Lower Bound & Upper Bound \\
\hline \multirow{2}{*}{$\begin{array}{c}\text { Traditional } \\
\text { flipping } \\
\end{array}$} & debate & 1.92884 & .015 & -10.6720 & -.9613 \\
\hline & control & 1.90194 & .007 & 1.5361 & 11.1113 \\
\hline \multirow[t]{2}{*}{$\begin{array}{l}\text { Debate- } \\
\text { oriented }\end{array}$} & $\begin{array}{c}\text { Traditional } \\
\text { flipping } \\
\end{array}$ & 1.92884 & .015 & .9613 & 10.6720 \\
\hline & Control & 1.95273 & .000 & 7.2249 & 17.0558 \\
\hline \multirow[t]{2}{*}{ Control } & $\begin{array}{c}\text { Traditional } \\
\text { flipping }\end{array}$ & 1.90194 & .007 & -11.1113 & -1.5361 \\
\hline & Debate-oriented & 1.95273 & .000 & -17.0558 & -7.2249 \\
\hline
\end{tabular}

According to the results of the Tukey test (table 4), the traditional flipping and debate-oriented groups significantly outperformed the control group in the apology post-test. This shows that both flipping methods had significant instructional effects on the appropriate use of apology. Moreover, there is a significant difference between the traditional flipping and debate-oriented flipping in favor of debateoriented flipping in terms of their effectiveness on the appropriate use of apology.

Table 5. Results of Tukey Post hoc Test for Request Post-test

\begin{tabular}{|c|c|c|c|c|c|}
\hline \multirow[t]{2}{*}{ (I) Group } & \multirow[t]{2}{*}{ (J) Group } & \multirow[t]{2}{*}{ Std. Error } & \multirow[t]{2}{*}{ Sig. } & \multicolumn{2}{|c|}{$95 \%$ Confidence Interval } \\
\hline & & & & Lower Bound & Upper Bound \\
\hline \multirow[t]{2}{*}{ Traditional flipping } & Debate-oriented & 1.94799 & .946 & -4.2463 & 5.5463 \\
\hline & Control & 1.94799 & .000 & 5.7537 & 15.5463 \\
\hline \multirow[t]{2}{*}{ Debate-oriented } & Traditional flipping & 1.94799 & .946 & -5.5463 & 4.2463 \\
\hline & Control & 1.94799 & .000 & 5.1037 & 14.8963 \\
\hline \multirow[t]{2}{*}{ Control } & Traditional flipping & 1.94799 & .000 & -15.5463 & -5.7537 \\
\hline & Debate-oriented & 1.94799 & .000 & -14.8963 & -5.1037 \\
\hline
\end{tabular}

According to the results of the Tukey test (table 5), the traditional flipping and debate-oriented groups significantly performed better than the control group in the request post-test. This shows that both flipping methods had significant instructional effects on the appropriate use of requests. However, there is no significant difference between the traditional flipping and debate-oriented flipping in terms of their effectiveness on the appropriate use of request.

\section{Discussion}

Three research questions were addressed in the present study. In this section, the obtained results are justified and compared with the findings of the previous studies.

To answer the first question regarding the effect of different types of flipped classroom on the Iranian upper-intermediate EFL learners' appropriate use of refusal, the mean scores of the traditional flipping, debate-oriented flipping and control groups were compared with each other in the pre-test and the post- 
test. While there was no significant difference between the mean scores of the three groups in the pretest, their post-test scores were significantly different. This led to the conclusion that different types of flipped classroom significantly affect Iranian upper-intermediate EFL learners' appropriate use of refusals in a significantly positive way. Moreover, it was found that there is no significant difference between the traditional flipping and debate-oriented flipping in terms of their effectiveness on the appropriate use of refusal.

To answer the second research question, which dealt with the effect of different types of flipped classroom on the Iranian upper-intermediate EFL learners' appropriate use of apologies, two one-way ANOVA tests were run, the results of which showed that different types of flipped classroom had a statistically significant and positive effect on the Iranian upper-intermediate EFL learners' appropriate use of apologies. Moreover, the debate-oriented flipping group significantly outperformed the traditional flipping group in the apology post-test. This indicates that the debate-oriented flipping method was of more effectiveness than the traditional flipping on the appropriate use of apologies.

Regarding the third research question on the effect of different types of flipped classroom on the learners' appropriate use of request, it was revealed that both flipping methods had significant effects on the participants' appropriate use of requests as compared with the control group. Moreover, there was no significant difference between the effectiveness of the two types of flipped classroom in the appropriate use of request.

In line with the findings of the present study, Hazaimeh and Altakhaineh (2019) showed that flipped classroom instruction was effective in raising the level of pragmatic competence among the participants. Also, consistent with this study,.Haghighi, Jafarigohar, Khoshsima and Vahdany (2018) investigated the effect of flipped classroom on EFL learners' appropriate use of refusal and showed a positive effect of flipped classroom in this regard.

Furthermore, the results of the present study are explicitly compatible with the research studies conducted by Al-Harbi (2015), Alsmari (2020), Al-Harbi and Alshumaimeri (2016), Al-Zahrani (2015), Amiryousefi (2017), Ekmekci (2017), Chen Hsieh et al. (2017), and Hung (2017), in which the flipped group learners consistently outperformed their control group counterparts in English language pragmatics.

Also, this study finding are supported by the results of the study by Katchamat (2018) which investigated the effect of the flipped classroom on pragmatic development, with emphasis on the use of apology strategies, and it was found that flipped classroom significantly affects the use of apology strategies.

In a more implicit sense, the results confirm the findings of Zhao, Liu and Su (2021) who showed the effectiveness of flipped classroom on English learning among EFL learners.

In justifying the findings, Bishop and Verleger' s (2013) constructive learning can be referred to according to which through flipped classroom, higher order cognitive processes including critical thinking, problem-solving, and decision-making are stimulated and this motivates language learners to become reflective learners. Moreover, the findings can be justified by referring to the argument that flipped classroom significantly leads to more learner participation in class activities, and this can 
enhance their pragmatic knowledge (Lai \& Hwang, 2016). The effectiveness of the flipped classroom can also be attributed to the quality of time which is spent inside the classroom (Davies, Dean, \& Ball, 2013). To be more specific, in traditional classrooms, a high amount of class time is devoted to teacher lecture and explanations, with little time for the communicative use of the speech act (Davies, Dean, \& Ball, 2013).

Another possible reason for the findings can be that implementing flipped classroom improves learners' motivation to work cooperatively and engage in collaborative learning, and consequently learn selfdirected learning skills (Chau\& Cheng, 2010). In addition, the findings can be justified by referring to the reasoning made by Chau and Cheng (2010), according to which flipped classrooms help students be more informed, independent and autonomous, and reflect on their strengths and weaknesses, and it promotes communication between students and teachers. The same argument has been put forth by Khadjieva and Khadjikhanova (2019).

The findings can also be attributed to the increased motivation of learners in the flipped classroom (Katchamat, 2018; Khadjieva \& Khadjikhanova, 2019), which may have caused significant improvements in learners' pragmatic knowledge. As another justification for the findings, it can be said that since learners have a positive attitude toward flipped classrooms, this has led to improvements in their pragmatic knowledge (Chandra \& Fisher, 2009; Finkbeiner, 2001; Najmi, 2015). Also, some opportunities provided by flipping method use such as simplicity of directed guidelines, active learning opportunities, and joint learning settings may help achieve English language acquisition (Gibson, 2008). Also closely related to the findings of the present study, it has been found that flipped classroom model increases student achievement, in turn, it leads to higher willingness to learn the subject (Abu Naba'h, Hussain, Al-Omari, \& Shdeifat, 2009; Ahmad \& Al-Khanjari, 2011; Anbarestani, 2009; Fahmi Bataineh\&Barjas Mayyas, 2017; Greene, 2013; Khadjieva\&Khadjikhanova, 2019; Sidman-Taveau, 2005). This can also be enumerated as a justification for the findings of the current study.

Moreover, the significant effect of the flipping method on self-esteem of students can be a justification for the findings (Jan, Soomro, \& Ahmad, 2017). That is, it is possible that flipping method has enhanced learners' self-esteem, and this has contributed to higher pragmatic knowledge. The conclusion made by Rastegar and Yasami (2014) according to which flipped classrooms increase English proficiency of EFL learners can also be taken as a potential reason for the findings of the present study. Another possible reason for the results of this study can be enhancement of the participants' sociolinguistic constraint awareness and consequent improvement of their pragmatic knowledge as a result of being exposed to flipping methods (Katchamat, 2018).

Another argument which can be put forth to justify the findings is that potentially learners' foreign language anxiety has been decreased as a consequence of their exposure to flipped classroom, and this has caused their pragmatic knowledge to be significantly increased. As another justifying argument, it can be said that possibly the learners' sense of having agency has been increased because of flipped classroom and this has encouraged them to learn pragmatics. 
It has also been argued that the flexible and accessible e-learning environment provided to learners in flipped classrooms can have contributed to pragmatic knowledge in them (Hazaimeh \& Altakhaineh, 2019). The findings can also be explained by saying that the personalization and individualization created by flipped classroom may have led to higher comfort level and consequently higher pragmatic knowledge among the learners. That is, possibly learner anxiety and stress have been reduced as a result of personalization (making learning more personal and individualized) created from using flipping method, and this has contributed to pragmatic knowledge among them. Moreover, the learners' increased class communication after using flipped classrooms may be another reason for significant increase in their pragmatic knowledge. In line with this, d'Inverno, Davis, and White (2003) showed that flipping leads to higher interaction levels among learners. Similarly, Heaslip, Donovan, and Cullen (2014) showed the effectiveness of flipping on learner engagement. Also, Godzicki, Godzicki, Krofel, and Michaels (2013) showed that flipping has a significant impact on learner communication activities. The researcher believes that probably learners' autonomy and self-confidence can play a mediating role in this regard. Also, taking the effect of personal responsibility on communication into account, it can be hypothesized that personal responsibility of the learners have increased as a result of the use of flipping, and this has led to more communication, and consequently better pragmatic knowledge among them as compared to the control group. Interestingly, flipping can significantly reduce learner shyness (Hughes \&Coplan, 2010), and this can contribute to improving learner pragmatic knowledge.

All in all, the results of the present study confirmed that as a result of using flipping methods, Iranian EFL learners' appropriate use of refusals, apologies and requests was improved significantly. Accordingly, EFL teachers are recommended to use flipping in an attempt to enhance EFL learners' English pragmatics learning. Given that pragmatics is an indispensable part of English learning, the finding of the present study is promising for ELT stakeholders especially EFL learners.

Based on the results of this study, it can be concluded that English teachers and learners should benefit flipped instruction in English classes. Interestingly, since in the existing literature (e.g., Dashtestani, 2013), it has been shown that both teachers and learners have a positive attitude towards such methods and prefer to use them in the English classes, planning and implementing some measures aimed at using flipping method in English classes are not misplaced. Therefore, it seems that the time has reached for the arrival of more technological instruments which pave the ground for flipped instruction in the English classes in Iran, as supplementary to traditional methods of ELT.

Accordingly, it can be concluded that flipping methods can be made use of to help students learn English pragmatics more effectively than the mainstream methods, participate in class activities, be more motivated to learn English, communicate more easily with their teachers and peers, and feel more comfortable and less anxious in the classroom. This requires macro-level strategies through which technological tools can be utilized in the English classes in the Iranian educational settings. The recent revisions and changes made in the English textbooks can be continued so that the need to incorporate technological tools in the English curricula can be fulfilled. 
Conflict of interest: The authors state no conflict of interest in the study.

Financial sponsor: The authors acknowledge that they have not received any financial support for all stages of the study, writing and publication of the paper.

Acknowledgment: We hereby appreciate all the participants of the study as well as all those participating in the implementation of this project.

\section{References}

Abu Nabah, A., Hussain, J., Al-Omari, A., \& Shdeifat, S. (2009). The effect of computer assisted language learning in teaching English grammar on the achievement of secondary students in Jordan. The International Arab Journal of Information Technology, 6(4), 431-440.

Agca, R.K., \& Ozdemir, S. (2012). Foreign language vocabulary learning with mobile technologies. Procedia - Social and Behavioral Sciences, 83, 781 - 785.

Ahmad, N., \& Al-Khanjari, Z. (2011). Effect of Moodle on learning: An Oman perception. International Journal of Digital Information and Wireless Communications, 1(4), 746752.

Al-Harbi, A. H. (2015). A flipped learning approach using social media in health informatics. Scientific Research, 6(13), 1466-1475.

Al-Harbi, S., \& Alshumaimeri, A. (2016). The flipped classroom impact in grammar class on EFL Saudi secondary school students' performances and attitudes. English Language Teaching, 9(10), 61-80.

AlSmari, N.A. (2020). The effect of flipped classroom instruction on developing Saudi EFL learners' comprehension of conversational implicatures. International Journal of English Linguistics, 10 (2), 107-127.

Al-Zahrani, A. M. (2015) From passive to active: The impact of the flipped classroom through social learning platforms on higher education students' creative thinking. British Journal of Educational Technology, 46(6), 1133-1148.

Amiryousefi, M. (2017). The incorporation of flipped learning into conventional classes to enhance EFL learners' L2 speaking, L2 listening, and engagement. Innovation in Language Learning and Teaching, 13(2), 1-15.

Anbarestani, M. (2009). The effects of CALL programs on expanding lexical knowledge of EFL learners among Iranian intermediate-level student. Retrieved from ganj.irandoc.ir.

Ary, D., Jacobs, L.CH., Sorensen Irvine, Ch.k., \& Walker, D.A. (2019). Introduction to research in education. Cengage Learning.

Ash, K. (2012). Educators Evaluate 'Flipped Classrooms'. Education Week. Retrieved from http://commons.marymount.edu/instructingonline/wpcontent/uploads/sites/135/2013/07/BetPractices-Flipped-Classroom.pdf.

Austin, J. L. (1962). How to do things with words. Cambridge, MA: Harvard University Press. 
Baranovic, K. (2013). Flipping the first-year composition classroom: Slouching toward the pedagogically hip. Retrieved from http://search.proquest.com/docview/1441087946?accountid=12206.

Basaran, S. (2019). Investigating university students' views on flipped classroom approach. Proceedings of INTED2019 Conference, 130-146.

Becker, B. W. (2013). Start flipping out with guide on the side. Behavioral and Social Sciences Librarian, 32(4), 257-260.

Bell, M.R. (2015). An investigation of the impact of a flipped classroom instructional approach on high school students' content knowledge and attitudes toward the learning environment. All Theses and Dissertations. 4444. Retrieved from https://scholarsarchive.byu.edu/etd/4444.

Berrett, D. (2012). How flipping the classroom can improve the traditional lecture. The Chronicle of Higher Education, 171-190.

Birjandi, P., \& Rezaei, S. (2010). Developing a multiple-choice discourse completion test of interlanguage pragmatics for Iranian EFL learners. ILI Language Teaching Journal (Special Issue: Proceedings of the First Conference on ELT in the Islamic World), 6 (1, 2), 43-58.

Bishop, J. L., \& Verleger, M. A. (2013). The flipped classroom: A survey of the research. Paper presented at the 120th ASEE Annual \& Exposition, Atlanta, USA.

Brame, C.J. (2013). Flipping the classroom. Received from http://cft.vanderbilt.edu/guides-subpages/flipping-the-classroom/

Butt, A. (2014). Student views on the use of a flipped classroom approach: Evidence from Australia. Business Education \& Accreditation, 6(1), 33-43.

Chandra, V., \&Fisher, D.L. (2009). Students' perceptions of a blended web-based learning environment. Learning Environment Research, 12, 31-44.

Chau, J., \& Cheng, G. (2010). Towards understanding the potential of e-portfolio for independent learning: A qualitative study. Australian Journal of Educational Technology, 26(7), 932-950.

Chen Hsieh, J. S., \& Marek, M. W. (2017). Using the flipped classroom to enhance EFL learning. Computer Assisted Language Learning, 30(1-2), 1-21.

Consolo, D. A. (2006). Classroom oral interaction in foreign language lessons and implications for teacher development. Linguagem \& Ensino, 9(2), 33-55.

d'Inverno, R., Davis, H., \& White, S. (2003). Using a personal response system for promoting student interaction. Teaching Mathematics and its Applications, 22(4), 163-169.

Dashtestani, R. (2013). Implementing mobile assisted language learning an EFL context: Iranian EFL teachers on challenges and affordance. JALTCAL Journal, 9(2), 149-146.

Davies, R. S., Dean, D. L., \& Ball, N. (2013). Flipping the classroom and instructional technology integration in a college-level information systems spreadsheet course. Educational Technology Research \& Development, 61(4), 563-580.

Davis, N.L. (2016). Anatomy of a flipped classroom. Journal of Teaching in Travel \& Tourism, 16(3), 228-232.

Doman, E., \& Webb, W. (2016). Does the flipped classroom lead to increased gains on learning outcomes in ESL/EFL Contexts?. The Catesol Journal, 28 (1), 39-67. 
Dooley, K. (2009). Intercultural conversation: Building understanding together. Journal of Adolescent \& Adult Literacy, 52(6), 497-506.

Ekmekci, E. (2017). The flipped writing classroom in Turkish EFL context: A comparative study on a new model. Turkish Online Journal of Distance Education, 18(2), 151-167.

Elyasi, L., \& Pourkalhor, O. (2014). The effect of recorded instructional TV programs and traditional teaching on Iranian high school students. Asian Journal of Management Sciences \& Education, 3 (3), 125-131.

Fahmi Bataineh, R., \& Barjas Mayyas, M. (2017). The utility of blended learning in EFL reading and grammar: A case for Moodle. Teaching English with Technology, 17(3), 35-49.

Finkbeiner, C. (2001). One and all in CALL? Learner-moderator-researcher. Computer Assisted Language Learning, 14(3-4), 339-361.

Gibson, S. (2008). Reading aloud: A useful learning tool? ELT Journal, 62(1), 118-130.

Goodwin, B., \& Miller, K. (2013). Evidence on flipped classrooms is still coming in. Educational Leadership, 70 (6), 78-80.

Greene, N. (2013). Computer Assisted Language Learning (CALL) for the inclusive classroom. Retrieved from Theses/Dissertations/ Professional Papers/

Haghighi, H., Jafarigohar, M., Khoshsima, H., \& Vahdany, F. (2018). Impact of flipped classroom on EFL learners' appropriate use of refusal: Achievement, participation, perception. Computer Assisted Language Learning, 1-33.

Haqqani, F., Rezaei, H., Bigzadeh, A., \& Eghbali, B. (2016). Flipped classes: An educational approach. Iranian Journal of Medical Education, 16, 31-49.

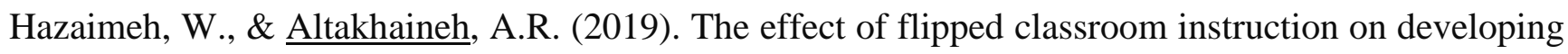
Emirati EFL learners' pragmatic competence. International Journal of Learning, Teaching and Educational Research, 127-143.

Heaslip, G., Donovan, P., \& Cullen, J. (2014). Student response systems and learner engagement in large classes. Active Learning in Higher Education, 15(1) 11-24.

Hung, H. (2015). Flipping the classroom for English language learners to foster active learning. Computer Assisted Language Learning, 28(1), 81-96.

Hung, H. T. (2017). Design-based research: Redesign of an English language course using a flipped classroom approach. TESOL Quarterly, 51(1), 180-192.

Ibarz, T., \& Webb, S. (2007). Listening to learners to investigate the viability of technology driven ESOL pedagogy. Innovation in Language Learning and Teaching, 1(2), 68-79.

Jan, M., Soomro, S.A., \& Ahmad, N. (2017). Impact of social media on self-esteem. European Scientific Journal, 13(23), 329-341.

Joshaghan Nezhad, M., \& Bagheri, F. (2018). The impact of a flipped classroom on student motivation and student learning in computer course. Research in Curriculum, 2(31), 110-126.

Kasper, G. (2000). Data collection in pragmatics, in Spencer-Oatey, H. (ed.) Culturally speaking (pp. 316-341). London \& New York: Continuum. 
Katchamat, P. (2018). The effect of flipped classroom instruction on appropriacy of English apology by Thai EFL learners. International Journal of Pedagogy and Teacher Education (IJPTE), 2, 113124.

Kaviani, H., Liaqatdar, M., \& Zamani, B. (2017). Flipped learning process: Representation of the curriculum experienced in higher education. Quarterly Student Curriculum in Higher Education, 8(15), 56-618.

Khadjieva, I., \& Khadjikhanova, S. (2019). Flipped classroom strategy effects on students' achievements and motivation: evidence from CPFS level 2 students at Wiut. European Journal of Research and Reflection in Educational Sciences, 7 (12), 120-130.

Kvashnina, O.S., \& Martynko, E.A. (2013). Analyzing the potential of flipped classroom in ESL teaching. iJet, 11(3), 49-58.

Lai, C.L., \& Hwang, G.J. (2016). A self-regulated flipped classroom approach to improving students' learning performance in a mathematics course. Computers \& Education, 100, 126-140.

Lee, W.T. (2009). EFL learners' pragmatic awareness: an analysis of four-university students in Taiwan. Journal of China Institute of Technology, 40, 629-652.

Leech, G. (1983). The principles of pragmatics. London: Longman.

Lin, P.L., \& Chen, H.M. (2016). The effects of flipped classroom on learning effectiveness: using learning satisfaction as the mediator. World Transactions on Engineering and Technology Education, 14(2), 231-244.

Mireille, F. (2014). The impact of using a flipped classroom instruction on the writing performance of twelfth grade female Emirati students in the Applied Technology High School (ATHS). M.A. dissertation, Faculty of Education, The British University, Dubai, Emirates.

Mobser Maleki S. (2015). The application and effect of the flipped on learning the activities of the 8th grade high school course work and technology lessons of Baharestan, Master's Thesis, Kharazmi University, Tehran.

Moranski, K., \& Kim, F. (2016). Flipping lessons in a multi-section Spanish course: Implications for assigning explicit grammar instruction outside of the classroom. The Modern Language Journal, 100 (4), 830-852.

Najmi, K. (2015).The effect of mobile-assisted language learning on guided writing skill of Iranian upper inter-mediate learners. Journal of Applied Linguistic and Language Research, 2(4), 42-52.

Narciss, S., \& Koerndle, H. (2008). Benefits and constraints of distributed cognition in foreign language learning: Creating a web-based tourist guide for London. Journal of Research on Technology in Education. 40(3), 281-307.

Rahmanpanah, H., \& Mohseni, A., (2017). Engagement and motivation in EFL classroom: Humanizing the course book or autonomy-supportive teaching climate? Journal of language and translation, 7(1), 69-88.

Rastegar, S., \& Yasami, F. (2014). Iranian EFL learners' proficiency levels and their use of apology strategies. Proceedings of International Conference on Current Trends in ELT, 1535-1540.

Reeve, J., \& Lee, W. (2014). Students' classroom engagement produces longitudinal changes in classroom motivation. Journal of Educational Psychology, 106(2), 527- 540. 
Rodríguez-Arancón, P., Arús,J., \& Calle, C. (2013). The use of current mobile learning applications in EFL. Procedia - Social and Behavioral Sciences, 103, 1189-1196.

Sadri, Z., Allami, H., \& Rezai, M.J. (2008). Telephone conversation closing strategies used by Persian speakers: Rapport management approach. International Journal of Foreign Language Teaching \& Research, 6 (21), 21-40.

Sahin, M. (2009). Second language vocabulary acquisition in synchronous computer-mediated communication. Eurasian Journal of Educational Research, 34,115-132.

Said Ahmed, M.E.A. (2016). The effect of a flipping classroom on writing skill in English as a foreign language and students' attitude towards flipping. US-China Foreign Language, 14(2), 98-114.

Sams, A., \& Bergmann, J. (2013). Flip your students' learning. Technology rich learning, 70(6), 51-69.

Searle, J.R. (1969). Speech acts. Cambridge: Cambridge University Press.

Senowarsito, I. (2013). Politeness strategies in teacher-student interaction in an EFL classroom context. TEFLIN Journal, 21(4), 82-96.

Sidman-Taveau, R.L. (2005). Computer-assisted project based learning in second language: Case studies in adult ESL. Retrieved from: https://etd.lib.metu.edu.tr/upload/12606252/index.pdf https://www.lib.utexas.edu/etd/d/2005/sidmantaveaur63568/sidmantaveaur63568.pdf.

Sung, K. (2015). A case study on a flipped classroom in an EFL content course. Multimedia-Assisted Language Learning, 18(2), 159-187.

Tomlinson, B. (2011). Materials development in language teaching (2 ${ }^{\text {nd }}$ ed). Cambridge, UK: Cambridge University Press.

Webb, M., Doman, E., \& Pusey, K. (2014). Flipping a Chinese university EFL course: What teachers and students think of the model. Journal of Asia TEFL, 11(4), 53-87.

Wistner, B., Hideki, S., \& Mariko, A. (2013). An analysis of the Oxford Placement Test and the Michigan English Placement Test as L2 proficiency tests. Retrieved from https://www.hosei.ac.jp/bungaku/museum/html/kiyo/58/articles/Wistner.pdf.

Zhao, L., Liu, X., \& Su, Y. (2021). The differentiate effect of self-efficacy, motivation, and satisfaction on pre-service teacher students' learning achievement in a flipped classroom: A case of a modern educational technology course. Sustainability, 13 (2888), 1-15. 